\title{
Personal Constructions of Biological Concepts - The Repertory Grid Approach
}

Thomas J. J. McCloughlin ${ }^{\star 1}$ And Philip S. C. Matthews ${ }^{2}$

$\approx$ This work discusses repertory grid analysis as a tool for investigating the structures of students' representations of biological concepts. Repertory grid analysis provides the researcher with a variety of techniques that are not associated with standard methods of concept mapping for investigating conceptual structures. It can provide valuable insights into the learning process, and can be used as a diagnostic tool in identifying problems that students have in understanding biological concepts. The biological concepts examined in this work are 'natural kinds': a technical class of concepts which 'appear' to have invisible 'essences' meaning carrying more perceptual weight than being perceptually similar. Because children give more weight to natural-kind membership when reasoning about traits, it would seem pertinent to apply such knowledge to deep-level research into how children reason in biology. The concept of natural kinds has a particular resonance with biology since biological kinds hold the distinction of being almost all natural kinds, such as when the same 'stuff or thing' takes many different forms. We have conducted a range of studies using a diversity of biological natural kinds, but in this paper, we wish to explore some of the theoretical underpinnings in more detail. To afford this exploration, we outline one case-study in a small group of secondary school students exploring the concept of 'equine' - that is, what is an equine? Five positive examples were chosen to engaged with by the students and one 'outlier' with which to compare the construction process. Recommendations are offered in applying this approach to biological education research.

Keywords: repertory grid analysis; biological concepts; mapping; natural kinds

$1 \quad{ }^{\star}$ Corresponding Author. Dublin City University, Ireland; tom.mccloughlin@dcu.ie.

2 Dublin City University, Ireland. 


\section{Osebnostni konstrukti bioloških konceptov - pristop repertoarnih mrež}

Thomas J. J. McCloughlin in Philip S. C. Matthews

$\propto$ Prispevek obravnava analizo repertoarnih mrež (ARM) kot orodje za preučevanje predstav bioloških konceptov študentov. ARM nudi raziskovalcem vrsto tehnik, ki niso povezane s standardnimi metodami konceptualnih zemljevidov za raziskovanje konceptualnih struktur. Zagotavlja lahko pomembne vpoglede $\mathrm{v}$ učni proces in je lahko uporabljen kot diagnostično orodje za definiranje problemov, s katerimi se spoprijemajo študentje pri razumevanju bioloških konceptov. Biološki koncepti, preučeni v tem prispevku, so »naravne vrste«: tehnični razred konceptov, za katere se »zdi«, da imajo nevidne esence večzaznavne teže, kot so zaznavno podobni. Ker dajejo otroci večji pomen uvrščanju naravnih vrst, ko sklepajo o značilnostih, se zdi koristno takšno znanje aplicirati v poglobljena raziskovanja o sklepanjih otrok v biologiji. Koncept naravnih vrst ima posebno resonanco z biologijo, saj biološke vrste vsebujejo razlikovanje, da so skoraj vse naravne vrste, kot na primer takrat, ko enaka »stvar ali zadeva « zavzame več različnih oblik. Opravili smo vrsto raziskav, uporabljajoč raznolikost bioloških naravnih vrst, ampak v tem prispevku želimo podrobneje raziskati teoretične podstati. Da si lahko dovolimo to preučevanje, orišemo študijo primera majhne skupine učencev predmetne stopnje, ki so preučevali koncept »konj«, tj. kaj je konj. Izbranih je bilo pet pozitivnih primerov koncepta in en primer osamelca, s katerim si pomagajo v procesu konstrukcije. Podana so priporočila za apliciranje tega pristopa $\mathrm{v}$ raziskovanju biološkega poučevanja.

Ključne besede: analiza repertoarnih mrež, biološki koncepti, mapiranje, naravne vrste 


\section{Introduction}

The field of biology education has been enriched by contributions from anthropology and cognitive science, particularly in elucidating concepts associated with natural kinds (Kripke, 1971, 1972; Mayr, 1942; Mill, 1843; Putnam, 1975; Quine, 1969; Wilkerson, 1995). Natural kinds can be considered in a weak and a strong sense. The strong sense is that natural kinds are precisely those kinds that science seeks to identify. The identification of a natural kind by science is a claim to have established how nature is divided at one of its many 'joints'. Thus, physics claims that the electromagnetic field is a natural kind, chemistry claims that the stuff labelled 'water' is just that material with composition $\mathrm{H}_{2} \mathrm{O}$ and is a natural kind. Historically, one aim of biology has been to delimit the notion of species to represent a set of natural kinds. However, given the difficulties that have accompanied this pursuit, there is reason to doubt if the concept of a species will be identified as representing a natural kind; therefore, a weak sense of natural kind is more relevant to biology where exceptions are permitted, and which we take as a demonstrative definition. See, for example, Wilkerson (1995) for a discussion of this point, and of natural kinds in general. Another sense of natural kinds is that they represent entities that may appear only to be definable, or describable, in terms of hidden essences. Often, they are the stuff of 'folk-biology', and as such have been investigated by many authors. Furthermore, biology education has been enriched by contributions from anthropology and cognitive science. The following are most noteworthy:

- $\quad$ Atran (1995a, 1995b) who proposed folk-biological constraints on taxonomies and the existence of a natural kind module in the mind;

- Keil (1989) who experimented with transformations on natural kinds;

- $\quad$ Springer and Keil (1991) and Gelman and Wellman (1991) who explored essentialistic thinking with respect to natural kinds;

- Wellman and Gelman (1992) who described biology as an innately constrained domain;

- Hatano and Inagaki (1994) who postulated the existence of a naïve biology which is an adaptive, causal, explanatory framework encompassing living things.

In particular, young children (and other lay people) have an intuitive sense of difference between types of animal. They recognize that, for example, lions and tigers may not interbreed, or that a tiger remains a tiger even if its manifest signs, such as stripes, are absent (viz Keil, 1989). It appears that humans have an innate sense of living creatures being of different kinds to 
inanimate matter. However, we believe that it is the sense that (young) humans have of the hidden essences of natural kinds that makes at least certain aspects of academic biology difficult to understand. The key problem is that the hidden essences of folk biology rarely, if ever, coincide with the natural kinds identified by the scientific discipline(s) of biology. Thus, as a biology teacher, one may be faced with the task of displacing or perhaps over-riding a student's strongly held belief. This facet of teaching and learning is, of course, familiar from the constructivist paradigm that has tended to dominate science education research in the last 25 years. We are at present undertaking a study of students' conceptions of species, particularly of equines. The aim of the work is to identify communalities and differences in the ways that students conceive of members of different species. We have found that repertory grid analysis (RGA), which is a method of investigating conceptual structures commonly used in the psychological literature, can be extremely useful in this research. In this paper, we give a brief account of RGA and illustrate some aspects of its utility in relation to a small pilot study undertaken with a group of school students. Repertory Grid analysis may be well known to practitioners in science education; however, the application to which it is being put here is a departure from previous research and practice. Further, it is our intention to demonstrate that whereas in the study 80 presented the topic was categorisation (of equines), it is suggested that all biological concepts may be represented using RGA.

\section{Concept mapping and repertory grid analysis}

The different types and uses of assessment techniques were reviewed by Novak and Mintzes (2001). However, RGA was not discussed by them; nor was it mentioned in Fisher, Wandersee and Moody (2000) which addressed the role of knowledge mapping in promoting meaningful learning in biology. Mohapatra and Parida (1995, pp. 663-681) used a concept graph technique to identify the location of alternative conceptions. Their technique is derived from Novak's (1990) system of using concept maps and vee diagrams as two metacognitive tools to facilitate meaningful learning. Mohapatra and Parida's system produces a matrix, the elements of which represent the strength of links between pairs of concepts as conceived by the corresponding group of subjects, and which have been scaled to values between o and 1. Lawson (1997, p. 292) points out that concept mapping is one of many techniques for externalising 'internal psychological structure'. He believes that concept mapping is similar to procedures which make use of multivariate statistical techniques of cluster analysis and multidimensional scaling procedures that repertory grid analysis 
utilises. Lawson (1997) also states that the repertory grid technique shares the same objective as concept mapping in attempting to produce 'a representation of the structure of a semantic space'. RGA has been widely put to use as a tool by psychoanalysts and psychiatrists to investigate the structure of a person's personality with a view to locating defects and making efforts to remedy afflictions from which the person might be suffering. As such, RGA is a key part of personal construct psychology (PCP), that proposes that a person constructs for $\mathrm{him} /$ herself a representation of their own reality. In such a system, the person is held to become analogous to a scientist, testing, making predictions, analysing situations, inferring and so on, as a means for construction. Kelly's often quoted phrase 'man as scientist' emphasises this point (Kelly, 1953/1991). However, such claims should be treated with caution because the analogy is simplistic (cf. Dunbar, 2002.). Kelly's influence has extended beyond the clinical setting and into educational psychology, especially into the constructivist paradigm. To use his terminology, a 'construct' is a way in which a person views aspects of the world as being similar or dissimilar. In this respect, constructs are fundamentally bipolar. Although Kelly did not intend his method to be applied to biological kinds such as horse, cow, sheep, etc., or indeed concretistic concepts from any of the disciplines of science, the purpose of this paper is to show that it does work as a method for conceptual analyses involving such kinds. Indeed over 30 years ago, Kelly's repertory grid technique was recommended as a technique to probe learners' prior knowledge (Sutton, 1980, p. 116). RGA has also been used in investigations of students' conceptual structures in some fields of physics (Fetherstonhaugh, 1994) and attitudes to science (Happs \& Stead, 1989). RGA makes use of multidimensional scaling (MDS) and other statistical techniques, such as principal component and factor analysis, that in themselves assume nothing of the background theory of RGA or PCP for their application. Such techniques have been used to good effect in, for example, the work of Atran (1999, p. 165), who used MDS to characterise the Itzaj snake classification. In passing it is worth noting that the majority of mathematical techniques employed in RGA programs can be found in commonly used statistical packages such as SPSS, Minitab, Statistica, and R. Furthermore, professional biologists have turned to such statistical methods in situations in which it is impossible to distinguish species without the precise measurement of prescribed parameters and executing the required algorithms (morphometric analysis cf. Quinn and Keough (2002)). An example of such a use is outlined below for the purpose of demonstration. It is important to emphasise that we are using the mathematical apparatus of RGA to analyse students' concepts in biology; we are not claiming this approach to be a contribution to PCP. Also, the small-scale study that we 
describe was chosen specifically to illustrate the way RGA can be applied in the context of biology education rather than to provide a thorough analysis of the students' conceptual structures.

Atran (1999) appears to have led the way for using organismal classificatory techniques to investigate the mental structures of biological data, by which he represented the mental relatedness of snakes in the minds of The Itzaj Maya. Although biologically, mimics are not closely related to the poisonous snakes they mimic, perceptually they are very closely related, e.g. Xenodon rabdocephalus is a mimic of Bothrops asper. Atran (1999) reported that the Itzaj Maya are motivated by the survival strategy 'better safe than dead', which constrains an initial classificatory identification. However, the Itzaj were still able to distinguish the mimics from their models. This is a result of a 'principled classification'. Fay et al. (2003) digested DNA samples of $C$. depauperata and, following amplification, separation was carried out using a polyacrylamide gel. The bands produced were scored as either absent or present producing a binary matrix. Principle coordinates analysis was performed on this matrix and axes extracted. This is a common technique in biology, see for example the following: Parnell and Needham (1998); Foley (2000a, 200ob); Blackstock and Ashton (2001); Abbott et al. (2002), Fay et al. (2002); Fay et al. (2003). Such mathematical treatment of the data (the data can be morphological, genetic, or dichotomous) can actually measure the state of such an alternative conception (to formal biology). A novel teaching and learning sequence followed by a repeat of the test could measure the shift in the conception if any, not necessarily conceptions related to classificatory schemata.

\section{Method}

A small group of students $(n=11)$ from a fifth year (student 16-17 years old) class group from the Irish Republic took part in this study. The repertory grid analysis package used was CIRCUMGRIDS III (Chambers \& Grice, 1987) working in MS-DOS format. (However, more sophisticated programs are available; see below.) The purpose of the work was to evaluate the use of an RGA program in investigating the ways in which this group of students categorized a set of animals, all but one of which were equines. The equines were: horse, pony, donkey, mule, zebra; and the non-equine was a goat. The purpose of including the non-equine was to discover if, as would be expected, the RGA method would show that this creature was (in relation to the others) considered by the students to be anomalous.

Initially, the students were asked to state what they thought to be key features of some equines, and their responses analysed. The most common six 
features they chose were the existence of stripes, the presence of a thick neck, and so on (see below). Note that these features are not necessarily those that are part of the classification system of academic biology. The RGA program was used to investigate how the six features were combined in the students' minds to form their conceptions of each of the six animals. In the terminology of RGA, the animals were used as 'constructs', and the features were the 'elements'. After accessing the menu page of the CIRCUMGRIDS III package, a choice is made of which analysis to use. The subjects were asked to enter data for (i) Bannister-Fransella and (ii) Bieri analyses, two out of a range of six analyses.

(i) Bannister-Fransella analysis compares the same elements and constructs of two grids. Each student entered the names of the six animals (constructs), i.e. horse, pony, donkey, mule, zebra, goat, and the six features (elements); i.e. stripes, thick neck, hardly any mane or tail, horse (equine) shape, chestnut, short face/small head. The program then presented the student with a list of the features and asked which of them is most 'zebra', or zebra-like, most horse-like and so on. The choices were scored on a set of six-point Likert scales, e.g. 'stripes' was scored as 1, and ranged to 'no-stripes' scored as 6 . This was repeated for all the feature/ animal combinations. The program requires the student to repeat the procedure, thus allowing a check on consistency to be made. The data is converted into two sets of grids (one of which is shown in Table 1) together with a series of measures that we describe below.

(ii) Bieri analysis is a means of eliciting the structure of constructs through ranking elements against constructs; i.e. here, the six features against each of the six animals. The software prompts for the number of constructs and elements (six in each case), and the names of constructs and elements. The program required the student to rank each feature against each animal using a seven point Likert scale ranging from +3 (strongly agree) through o to -3 (strongly disagree). For example, suppose a construct is envisaged as a line with, say, 'zebra' being one pole and 'notzebra' at the other. Then, if 'stripes' is placed on this line, the closer it is placed to the 'zebra' end (limit +3 ), the more significant this feature is to the student's conception of 'zebra'. The output from the program is another grid, illustrated in Table 2, and various statistical data, much of which is not relevant to our discussion. 


\section{Results}

\section{Bannister-Fransella Analysis}

Following the student's input of data, the program outputs the two grids (see Table 1) and, for each of them, it compares the entries for the pairs of animals. It does this by computing the correlation coefficients for each pair and rank ordering them. The ranks are used to calculate a value for the 'intensity', that provides a measure of the degree of structure in the student's system of classification. In our investigation, intensity scores were sometimes found to vary markedly between students, thus indicating considerable individual differences in how the subjects attributed animals to features.

Table 1. One of the grids of ranks of relevance entered by Student A

\begin{tabular}{lcccccc}
\hline Construct & Stripes & Neck & Mane/tail & Horse shape & Chestnut & Face \\
\hline Horse & 6 & 2 & 5 & 1 & 4 & 3 \\
Pony & 6 & 3 & 5 & 1 & 4 & 2 \\
Donkey & 6 & 2 & 5 & 1 & 4 & 3 \\
Mule & 6 & 2 & 5 & 1 & 4 & 3 \\
Zebra & 1 & 4 & 5 & 2 & 6 & 3 \\
Goat & 1 & 4 & 5 & 2 & 6 & 3 \\
\hline
\end{tabular}

Another measurement is the consistency between the two grids; in effect, this is a calculation of Spearman's rank correlation coefficient for the combined data of both grids. The interpretation of grids that show low consistency has to be treated with caution. Low consistency indicates a degree of uncertainty in the student's mind about the relation between the features and constructs with which she is presented.

\section{Bieri Analysis}

In Bieri analysis, the program ultimately produces an output that gives a visual display of the relationship between the elements and constructs. Initially, however, a grid is produced showing the data entered by the student. See Table 2 for the grid entered by Student B. The grid is used to compute a set of correlation coefficients, from which first, second and third principal components are computed using the standard techniques of statistical analysis. In the majority of cases, the variability in the data can be accounted for by just two components 
and the first and second components are plotted by the software. If required, the data can be entered into SPSS or similar and a three-dimensional principal components plot can be obtained. Figures 1, and 2 illustrate principal components plots produced by two of the students.

Table 2. Bieri analysis grid of scores entered by Student B

\begin{tabular}{lcccccc}
\hline Construct & Stripes & Neck & Mane/tail & Horse shape & Chestnut & Face \\
\hline Horse & -3 & 2 & 3 & 3 & -3 & 3 \\
Pony & -3 & 1 & -1 & 0 & -2 & 2 \\
Donkey & -3 & 2 & 1 & 0 & -2 & 2 \\
Mule & -2 & 1 & -1 & 0 & -2 & 2 \\
Zebra & 3 & 2 & -2 & -3 & -2 & 2 \\
Goat & -3 & -2 & -1 & -2 & 1 & -2 \\
\hline
\end{tabular}

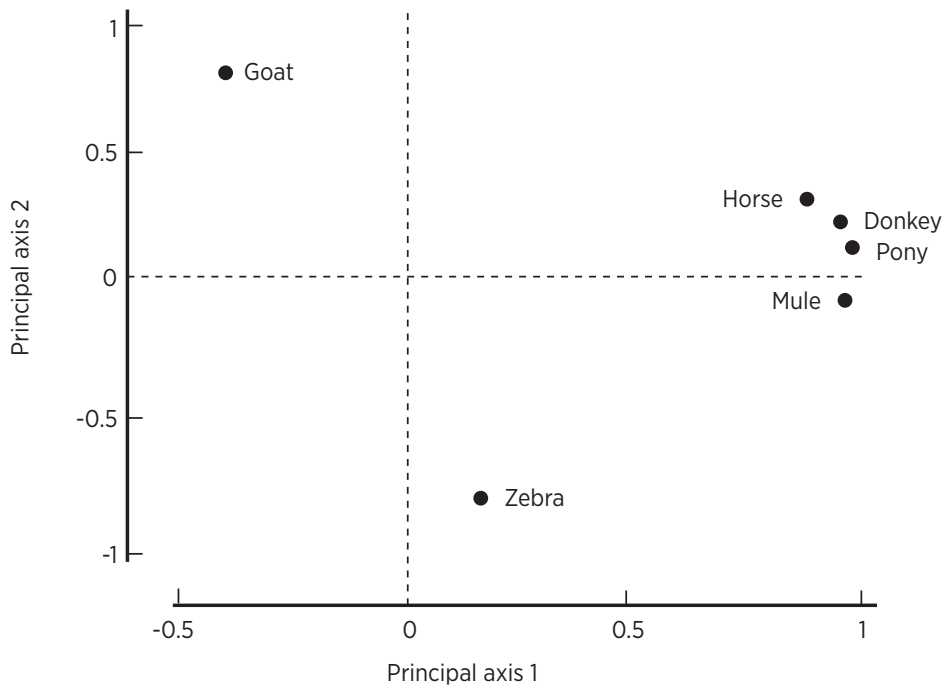

Figure 1. Principal components plot for the date entered by student B (Table 2). Note: for the sake of clarity, the plots in Figures 1 and 2 have been re-drawn rather than simply copied from the RGA program output 


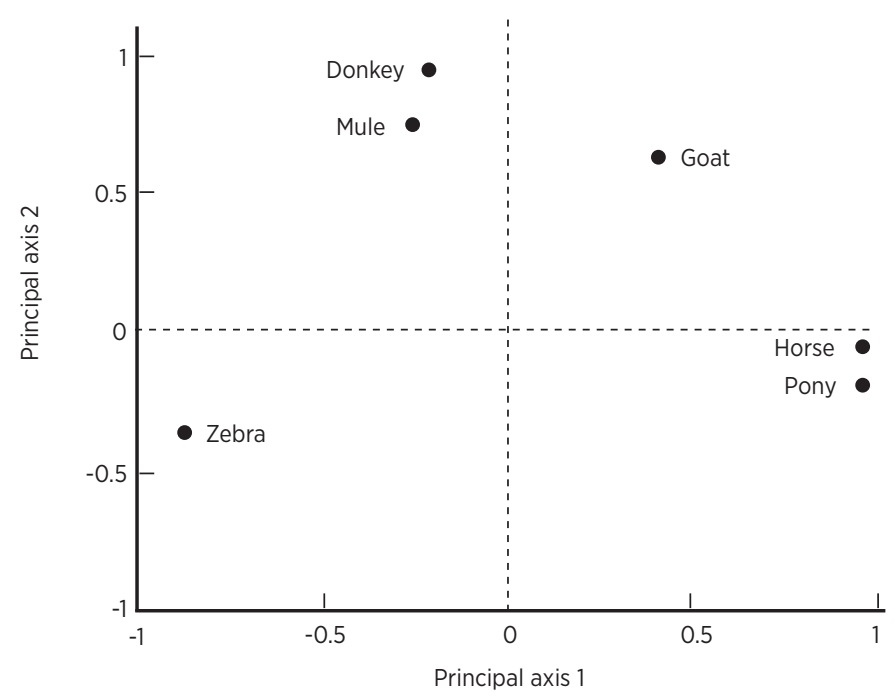

Figure 2. Principal components plot for Student C

A general point is that constructs located close to each other may be interpreted as occupying a similar conceptual space. Figure 1, shows that Student $\mathrm{B}$ regards horse, pony, donkey and mule as being very similar. In contrast, this student views goat and zebra as markedly different from those four animals, and from each other. Student C's results plotted in Figure 2 show that he viewed horse and pony as being closely related, as were donkey and mule; but these pairs were separated from each other. The implication is that this student had a subtler way of categorising these four animals than Student B did.

However, zebra and goat are again separated from the other four creatures, and from each other. More advanced repertory grid software goes further and measures the relatedness of the constructs, draws a cluster analysis diagram (resembling a phylogenetic tree), and compares the grids of a relatively large number of individuals, e.g. of a class group. (McCloughlin \& Matthews, 2001, 2002). Cluster analysis can be a powerful tool in analysing categorisation data (cf. Bailenson et al. (2002)), and the results of the formal scientific cluster analysis are comparable to the results of Repertory Grid Analysis. For example, the classification (Figure 3 ) is very different from that below in the cluster diagram (Figure 4) even though the original data was the same. This is because cladistics groups taxa according to special similarity using discrete characters rather than an overall similarity computed from the complete matrix (Schuh, 2000, p. 9). Repertory Grid software (e.g. RepGrid 2.0) typically perform cluster analysis (Figure 4) on both the features and the concepts, and it is 
possible to plot concepts within the psychological space of the features. Cluster analysis of the features or attributes of concepts allows the researcher to see if certain features are superfluous to the test instrument. If several features for a number of learners were tightly clustered at, say, 90\%, it is unlikely that all those features are needed to gain any meaningful information about the learners' concepts. In both the instances presented here, it must be remembered that what is plotted are mental representations of the learner's conceptions of the concepts encountered.

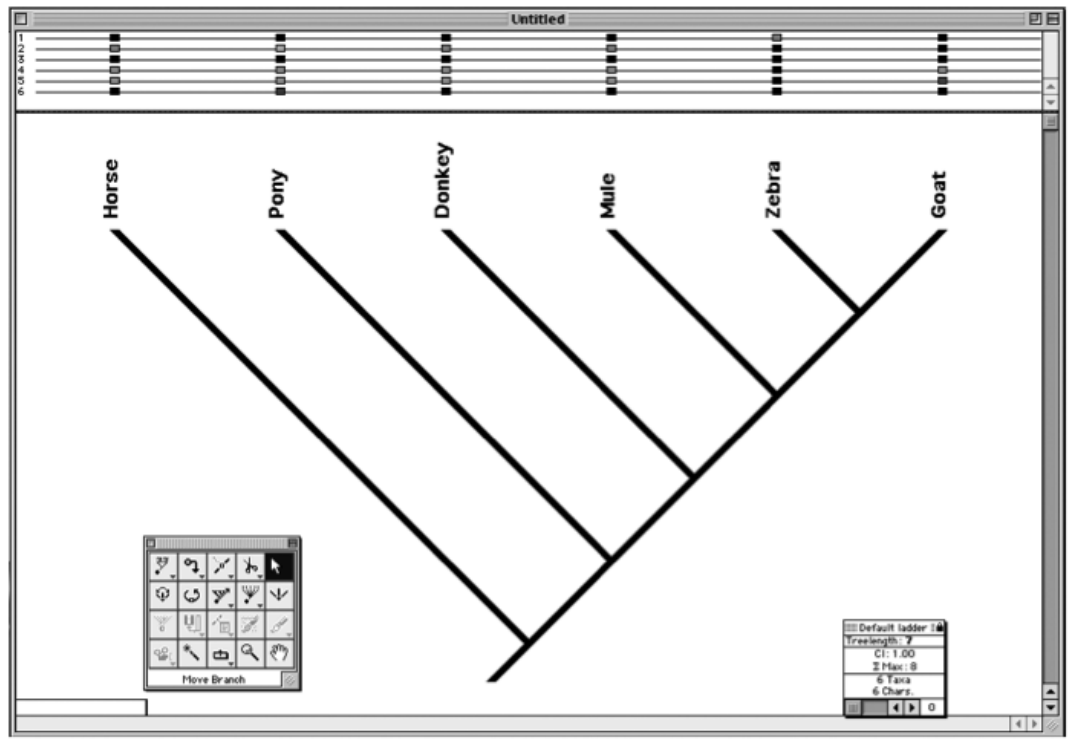

Figure 3. A dendrogram (i.e. cladogram) of the data from Table 1. entered into MacClade ${ }^{\text {mt }}$ cladistics software 
FOCUS: student A

Elements: 6, Constructs: 6, Range: 1 to 6, Context: pre-pilot

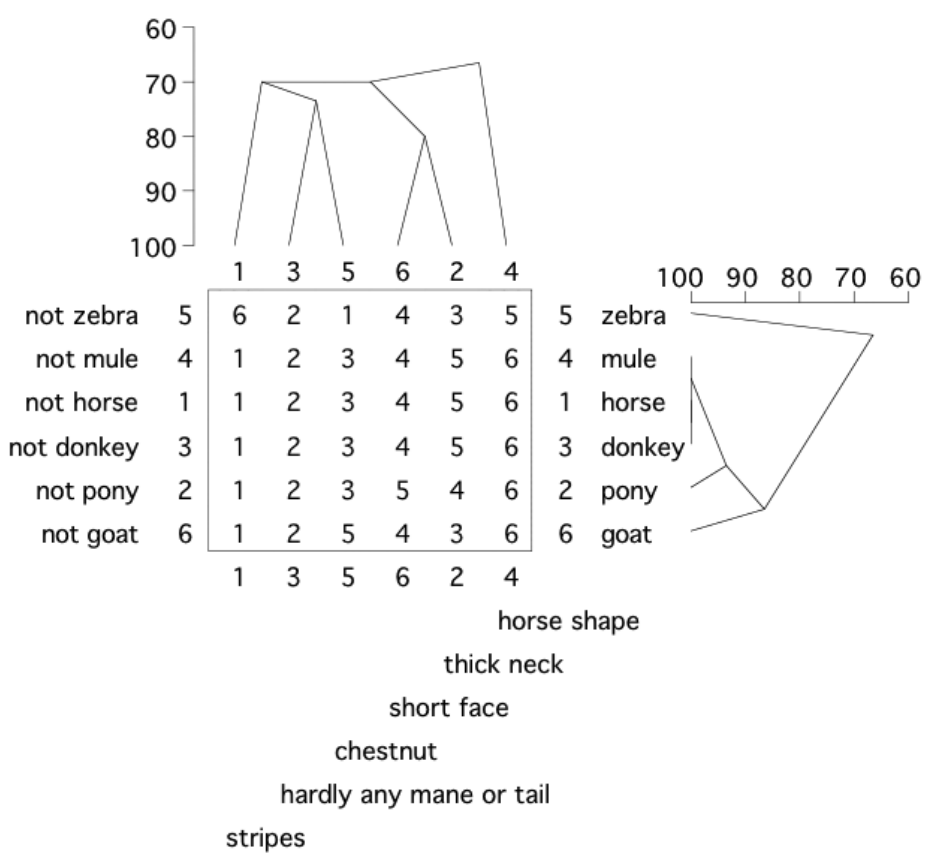

Figure 4. Output of FOCUS program of the RepGrid 2.0 package

\section{Discussion}

As mentioned earlier, the Bannister-Fransella printout provides intensity scores for every grid (two for each person) and a consistency score for each pair of grids. The scores and the grids themselves say something about the learner and that which is to be learned. Bannister and Fransella, (1977, p. 60) note that 'The lower the intensities score, the more disordered is one's thinking. The consistency value indicates the degree of stability between grids. Thus, a low consistency score indicates that the person is a disordered thinker, in the sense that $\mathrm{s} /$ he has no decided opinion on the way the elements should be ordered under the constructs. Perhaps paradoxically, low consistency means having the greatest cognitive complexity. If the subject could memorise their rating on the first test and replicate it in the second, the consistency scoring would be compromised; but this situation is unlikely, particularly if a period were to elapse between the tests. More work needs to be done to identify the relationship between complex concepts and intensity scores. If a learning strategy were to intervene between grid elicitations, the educator would hope that the 
second intensity score would be higher than the first (unless it was high in the first place). The comparison would indicate the quality of learning. Grids could be used to investigate the nature of the problem in the learning domain if one exists. We have found that it is instructive to compare the grids of learners with those of experts. One should be careful in interpreting principal components plots and taking them at face value.

Contrary to our expectations, one student, $\mathrm{D}$, had linked 'stripes' quite strongly to 'horse' and 'pony' as well as to 'zebra' (although not to 'goat'). That is, $\mathrm{D}$ (unlike the other students) did not use 'stripes' as a major way of discriminating between 'zebra' and 'horse'. We discovered the significance of this during an interview with the student. She was a member of the local equestrian club and had held a strong interest in horses for much of her life. She knew that it was possible for stripes to appear on the legs of newly born foals and then fade as they matured.

However, characterising 'zebra' as a striped animal took priority over all other features for all the students, including D. In interviews with the students prior to them completing the grids, it was clear that they knew that zebras are equines ('zebras are horses with stripes'); however, their attention appears to have been constrained by the obvious striped feature of these animals. Indeed, in an earlier remark, we said that we included 'goat' in the list of six animals to see if the RGA method would result in this animal being isolated from the equines. This did, in fact, prove to be the case; however, the separation/isolation of 'zebra' demonstrates the extent to which a single perceptual feature (stripes) can dominate students' thinking. Thus, the relationship between concepts of differing relevancy to the student or the educator may be investigated. Bannister-Fransella analysis is better suited to elucidating the features of structures of biological concepts in the individual rather than in a group unless some further manipulation is done. One form that this can take is tallying the scores for each characteristic (element) of a construct, yielding a matrix for the study group. This, for example, can show the most important feature used to characterise 'horse', 'pony', etc.; and each could be ranked. In our case, eight students believed that the general 'horse (equine) shape' was most important, but only one thought this to be so for a 'short face and small head'. The latter individual was not very familiar with horses, all the others being equestrians. However, even some of these students did not realise how ubiquitous the presence of a chestnut is among the equidae. It is interesting to note that when the students were asked to explain what 'horse (equine) shape' meant, they could not; many stated that 'you just know it or you don't'. One must be careful when proposing that single features (elements) are dominant over others; the fact is that, for example, the 
construct, 'horse' is being characterised by the balance of a small set of competing features. In some cases, two different animals might both justifiably an identical score on a particular characteristic. If the repertory technique is done in such a way (as in this case) that all constructs are required to receive a rank or score, then allocating a high score or rank to one element will have a knock-on effect in the allocation of scores/ranks to the other constructs.

An interesting problem is to analyse why different elements may be given a different emphasis by different people. Here the roles of language, experience and culture need to be addressed. The choice of elements in this pilot project was based on perceptual entities, whether they be a part of an animal (e.g. head) or a general essentialistic perception (general equine shape). However, ultimately, behind this interaction of competing features lies the core, the construct, of the species being recognised. The plots in Figures 1 and 2 represent 'maps' of the constructs in element space (element points can also be plotted in construct space). These maps are very different from the mapping techniques discussed in Fisher, Wandersee and Moody (2000) and Novak and Mintzes (2001). However, in our view they can be held to represent maps of a student's conceptual space; or, in simple terms, as 'concept maps', albeit of a special kind.

\section{Educational implications}

Repertory grid analysis allows biology educators an access point for research into their students' learning using powerful mathematical tools that are widely available. It is a technique that can usefully be employed over a wide range of ages, perhaps from late primary into tertiary education. Ideas can be elicited, whether finding out prior knowledge, teasing out alternative conceptions or investigating ideas relating to specific tasks set for research purposes. The technique is best suited to researchers until such time that a means for allowing classroom teachers to use it as an assessment tool can be put forward. Even where RGA is put forward as an alternative or form of concept mapping, it is not an advantage to make such a comparison since concept mapping itself has waxed and waned as an assessment and learning tool. The technique can be used diagnostically and allows the biology researcher/educator to gain a visual impression of how a student's concepts are related to each other. It can be used to give an overview of the conceptual structures of a class group. We have found it instructive to compare the plots of students with those of experts. The information contained in the principal components plots of expert and novice can give an indication to what remediation might be necessary to bring those of the students more into line with those of the expert's. Of singular importance is 
the fact that the researcher/educator can gain an appreciation of how ideas are modelled or structured by the students. In all these respects RGA can be used by researcher and teacher alike to evaluate teaching and learning. However, rather than being merely an alternative to concept mapping or other assessment techniques, RGA permits the researcher / educator to examine the 'apophatic' aspect of conceptual knowledge: i.e. saying what something IS NOT as opposed to the 'cataphatic' aspect, i.e. delineating what something IS within the same proposition. Concept mapping and other related techniques can be made amenable to mathematics but such application of ranks or scores are elicited differently and are not intrinsic to the method.

\section{References}

Abbott, R. J., James, J. K., Forbes, D. G., \& Comes, H. P. (2002). Hybrid origin of the Oxford Ragwort, Senecio squalidus L: morphological and allozyme differences between S. squalidus and S. rupestris Waldst. and Kit. Watsonia, 24(1) 17-30.

Atran, S. (1995a). Causal constraints on categories and categorical constraints on biological reasoning across cultures. In D. Sperber, D. Premack \& A. J. Premack, Causal Cognition: a multidisciplinary debate (pp. 316-340). Oxford: Clarendon Press.

Atran, S. (1995b). Cognitive foundations of natural history. Cambridge, Cambridge University Press. Atran, S. (1999). Itzaj Maya Folkbiological Taxonomy: Cognitive Universals and Cultural Particulars. In D. L. Medin \& S. Atran (Eds.), Folkbiology (pp. 119-213) Cambridge, Massachusetts: MIT Press. Bailenson, J. N., Shum, M. S., Atran, S., Medin, D. L., \& Coley, J. D. (2002). A bird's eye view: biological categorization and reasoning within and across cultures. Cognition, 84(1), 1-53. Bell, B. (1981a). What is a plant? Some children's ideas. New Zealand Science Teacher, 31(3), 10-14. Bell, B. (1981b). When is an animal not an animal? Journal of Biological Education, 15(3), 213-218. Bell, B., \& Baker, M. (1982). Toward a scientific concept of animal. Journal of Biological Education, 16(3), 197-200.

Berlin, B., Breedlove, D., \& Raven, P. (1973) General principles of classification and nomenclature in folk biology. American Anthropologist, 87(1), 298-315.

Blackstock, N., \& Ashton, P. A. (2001). A re-assessment of the putitive Carex flava agg. (Cyperaceae) hybrids at Malham Tarn (v.c.64): A morphometric analysis. Watsonia, 23(4), 505-526.

Chambers, W. V., \& Grice, J. W. (1986). Circumgrids: A repertory grid package for personal computers. Behavior Research Methods, Instruments, and Computers, 18(5), 468-468.

Dunbar, K. N. (2002). Understanding the role of cognition in science: The Science as Category framework. In P. Carruthers, S. Stich \& M. Siegal (Eds.), The cognitive basis of science (pp. 154-170). Cambridge: Cambridge University Press.

Fay, M. F., Gernandt, D. S., Cowan, R. S., Kitchen, M. A. R., Kitchen, C., \& Rich, T. C. G. (2002). Parentage of an unknown member of the Sorbus latifolia (Lam.) Pers. group (Rosaceae). Watsonia, 
24(1), 91-100.

Fay, M. F., O’Rourke, A., \& Rich, T. C. G. (2003). A preliminary investigation of genetic variation in

Western European Carex depauperata Curtis ex With. (Cyperaceae), Starved Wood-sedge. Watsonia, 24(4) 507-511.

Featherstonhaugh, T. (1994). Using the Repertory Grid to Probe Students' Ideas about Energy.

Research in Science and Technological Education, 12(2), 117-127.

Foley, M. J. Y. (2000a). A morphological comparison between some British Orobanche species (Orobanchaceae) and their closely-related, non-British counterparts from continental Europe:

Orobanche reticulata Wallr. s.l. Watsonia, 23(2), 257-267.

Foley, M. J. Y. (200ob). A morphological comparison between some British Orobanche species (Orobanchaceae) and their closely-related, non-British counterparts from continental Europe: Orobanche rapum-genistae Thuill. s.l. Watsonia, 23(2), 413-419.

Fransella, F., \& Bannister, D. (1977). A manual for repertory grid techniques. London: Academic Press. Gelman, S., \& Wellman, H. (1991). Insides and essences: early understanding of the non-obvious.

Cognition, 38(3), 214-44.

Gunstone, R. F. (1991). Learners in science education. In P. Fensham (Ed.), Developments and dilemmas in science education (pp. 73-95). London: Falmer Press.

Happs, J. C., \& Stead, K. (1989). Using the Repertory Grid as a Complementary Probe in Eliciting Student Understanding and Attitudes towards Science. Research in Science and Technological Education, 7(2), 207-220.

Hatano, G., \& Inaki, K. (1994). Young children's naive theory of biology. Cognition, 5o(1-3) 171-188.

Keil, F. C. (1996). Concepts, kinds and cognitive development. Cambridge, MS: MIT Press.

Kelly, G. A. (1953/1991). Psychology of personal constructs. Volume 1 - A theory of Personality.

London: Routledge.

Kelly, G. A. (1969). Ontological acceleration. In B. Maher (Ed.), Clinical psychology and personality: the selected papers of George Kelly (pp. 94-113) New York: Wiley.

Kripke, S. (1971). Identity and necessity. In M. K. Munitz (Ed.), Identity and Individuation (pp. 135-164). New York: New York University Press.

Kripke, S. (1972). Naming and necessity. In D. Davidson \& G. Harman (Eds.), Semantics of Natural Languages (pp. 253-355, with addenda pp. 763-769). Dordrecht: Reidel.

Lawson, M. J. (1997). Concept mapping. In J. P. Keeves (Ed.), Educational research methodology and measurement, an international handbook (2nd edition). Oxford: Pergamon.

Maddison, D. R., \& Maddison, W.P. (2011). MacClade v4.08. Retrieved 30. 1. 2017 from http:// macclade.org/macclade.html.

Mayr, E. (1942). Systematics and the Origin of Species, from the Viewpoint of a Zoologist. Cambridge: Harvard University Press.

McCloughlin, T. J. J., \& Matthews, P. S. C. (2001). Studying the learning of biological natural kind concepts. Proceedings of the third international conference of the European Science Education Research Association on: Science Education Research in the Knowledge Based Society. August 2001, 
Thessaloniki (Greece).

Mill, J. S. (1843/1973). A System of Logic, Ratiocinative and Inductive. Being a Connected View of the Principles of Evidence and the Methods of Scientific Investigation. Collected Works of John Stuart Mill (Vols. VII-VIII). Toronto: University of Toronto Press.

Mintzes, J. J. Wandersee, J. H., \& Novak, J. D. (2001). Assessing understanding in biology. Journal of Biological Education, 35(3), 118-124.

Mohapatra, J. K., \& Parida, B. K. (1995). The location of alternative conceptions by a concept graph technique. International Journal of Science Education 17(5), 663-681.

Novak, J. (1990). Concept mapping: a useful device for science education. Journal of Research in Science Teaching, 27(10), 937-949.

Osborne, R. J., \& Freyberg, P. (1987). Learning in Science: the implications of children's science.

London: Heinemann.

Parnell, J., \& Needham, M. (1998). Morphometric variation in Irish Sorbus L. (Rosaceae). Watsonia, $22(2) 153-161$.

Putnam, H. (1975). Mind, Language and Reality. Philosophical Papers. Volume 2. Cambridge: Cambridge University Press.

Quinn, G. P., \& Keough, M. J. (2002). Experimental Design and Data Analysis for Biologists.

Cambridge: Cambridge University Press.

Quine, W. V. (1969). Natural kinds. In J. Kim \& E. Sosa (Eds.), Ontological Relativity and Other Essays (pp. 114-138). New York: Columbia University Press.

Schuh, R. T. (200o). Biological Systematics: Principles and Applications. Ithaca: Cornell University Press.

Shaw, M. L. G. (1981). Recent advances in personal construct technology. London: Academic Press. Springer, K., \& Keil, F. C. (1991). Early differentiation of causal 363 mechanisms appropriate to biological and non-biological kinds. Child Development, 6o(3)637-648.

Sutton, C. R. (1980). The learner's prior knowledge: a critical view of techniques for probing itsorganisation. European Journal of Science Education, 2(2), 107-120.

Wellman, W. H., \& Gelman, S. A. (1992). Cognitive development: foundational theories of core domains. Annual Review of Psychology, 43(1) 337-375.

Wilkerson, T. E. (1995). Natural Kinds. Aldershot: Avebury. 


\section{Biographical note}

Thomas J. J. McCloughlin, $\mathrm{PhD}$, is a biologist, science educator and educator of student teachers at Dublin City University. He has taught biology and general science in primary, secondary and tertiary levels and his particular interests are cognition of biological concepts, cognitive acceleration and transdisciplinary research. He maintains scientific research in plant distribution and teratology and population dynamics and phylogenetics of aquatic trematode parasites. This work in turn informs his study of cognition through transfer of statistical analyses from biological research to the cognitive domain. $\mathrm{He}$ also has an interest in Byzantine art and philosophy which he pursues as a painter of icons and research in neo-Platonic speculation found in various writers.

Philip S. C. Matthews, PhD, is a chemist and science educator. He taught chemistry and general science at secondary school. He was registrar of the largest secondary teacher education programme in Ireland and senior lecturer in science education at Trinity College, Dublin for many years. He was Irish coordinator of the ROSE project and established the MSc in Science Education at TCD, the first in the country, and was involved in many projects and supervision of students. He is currently emeritus senior lecturer in science education. Among his research interests are mathematical models of science evaluation and causal pathway analysis. 